\title{
15. GENESIS AND EVOLUTION OF SMALL-SCALE STRUCTURES IN THE TOE OF THE BARBADOS RIDGE ACCRETIONARY WEDGE ${ }^{1}$
}

\author{
K. M. Brown ${ }^{2}$ and J. Behrmann ${ }^{3}$
}

\begin{abstract}
Cores from Leg 110 document the development of small-scale structures generated both during the initial propagation of the basal décollement zone into the abyssal plane section and the subsequent thickening of the wedge. At the macroscopic accretionary front, sub-horizontal compressive stresses become localized in the off-scraped section rather than in the underthrust sediments. In contrast, strata associated with the basal décollement zone may experience layer parallel extension resulting from a combination of simple shear and possible flattening strains (with the latter being the possible consequence of increased tectonic loading due to the thickening of the overlying wedge). The zone of intense scaly fabrics associated with the basal décollement and other thrusts appears to thicken with increasing displacement. This thickening, together with increasing numbers of thrusts (of both an in-sequence and out-of-sequence nature), may account for why $50 \%$ of the volume of the wedge is affected by scaly fabrics of Site $674,18 \mathrm{~km}$ back from the accretionary front. General bedding and thrust dips increase back in the wedge, most probably in response to both folding and back rotation of imbricate thrusts. Intense stratal disruption, syntectonic carbonate veins, occasional isoclinal folds (with axial planar fabrics), and web structures are all developed by $18 \mathrm{~km}$ from the accretionary front. At this point, the sediments still have porosities in excess of $40 \%$, and the small-scale structures are found at present depths of less than 400 mbsf. Apparently, these familiar fabrics of ancient accretionary wedges can develop at shallow depths in porous sediments soon after accretion.
\end{abstract}

\section{INTRODUCTION}

In combination with DSDP Leg 78A, Leg 110 offers a unique opportunity to document the small-scale structural evolution in the frontal $18 \mathrm{~km}$ of the developing Barbados Ridge accretionary wedge. Eight holes have now been drilled in a transect across the toe of the wedge and the abyssal plain. We use the observed small-scale structures to infer the strain history of the Pleistocene to Eocene abyssal plain section during the encroachment of the accretionary wedge, initial off-scraping of the section, and subsequent rapid tectonic thickening. In addition, ODP Leg 110 (Site 671) penetrated the basal décollement zone, developed along the lower Miocene horizon at the toe of the accretionary complex, and continued down some $150 \mathrm{~m}$ into the underthrust Oligocene and Eocene section below. This Oligocene and Eocene material was again encountered above the basal décollement in the western portion of the transect (Site 674) within the accretionary complex ( $18 \mathrm{~km}$ from the accretionary front). This leads to the interesting possibility that either underplated material was sampled during Leg 110 or that the basal décollement was at a deeper level during initial off-scraping in the past. Although the small-scale structures cannot provide a definitive explanation for how the Oligocene-Eocene sequence came to be in the wedge at Site 674, it is argued from larger scale geometrical considerations (see Brown et al., this volume) that underplating is a likely explanation.

From the data collected during DSDP Leg 78A and ODP Leg 110 we can derive a generalized model of the small-scale structural evolution within the modern accretionary wedge in which there are several structural domains (Fig. 1). The subsequent descriptions of the small-scale structural development in

\footnotetext{
${ }^{1}$ Moore, J. C., Mascle, A., 1988. Proc. ODP, Sci. Results, 110: College Station, TX (Ocean Drilling Program).

2 Earth Sciences Board, University of California at Santa Cruz, Santa Cruz, CA 95064 .

${ }^{3}$ Institut für Geowissenschaften und Lithospharenforschung, Universität Giessen, Senckenbergstr. 3, D6300, Giessen, Federal Republic of Germany.
}

the toe of the Barbados accretionary wedge have been subdivided in the following manner: (a) Pre-accretion structures affecting the abyssal plain sediments (taken from Site 672); (b) Frontal accretion structures formed during initial off-scraping (taken from Sites 671, 675, 676, 541, and 542); (c) Secondary or subsequent thickening structures in the interior regions of the wedge $12-18 \mathrm{~km}$ from the deformation front (taken from Sites 673 and 674); (d) Structures formed during underthrusting and possible underplating (taken from Sites 671 and 674).

ODP Leg 110 provides a basis for comparing models derived from ancient accretionary terranes (such as those derived for Kodiak Island by Fisher and Byrne, 1987), with a modern example in the form of the Barbados Ridge accretionary complex. For example, fabrics and structures at Site 674 (the hole farthest from the trench), are mesoscopically similar to those commonly observed in ancient accretionary terranes and provide a valuable link between studies in ancient and modern accretionary systems.

The following definitions will be used in the subsequent descriptions and discussion:

1. Scaly fabrics defined by the mesoscopic characteristics of anastomosing, polished and slickensided curviplanar fracture surfaces that delineate phacoids (Plate 1.1). They have commonly been described in fault zones that affect partly lithified muds in accretionary wedges and orogenic belts (see Cowan, 1974; Byrne, 1984; Lundberg and Moore et al., 1986).

2. Stratal disruption (see review by Lundberg and Moore 1986), occurs in zones of lithologic contrast, where relatively competent units are extended and are disrupted as a result of shear (Plate 1.2), while incompetent muds are commonly affected by scaly fabrics.

3. Mud-filled vein structures consist of curviplanar to planar, dark clay-rich surfaces or seams (Plate 1.3). Individual seams contain sediment that appears finer grained than the surrounding sediment. Commonly some of the vein "filling" is altered local sediment and the term may be somewhat misleading (see Cowan, 1982b; and reviews by Knipe, 1986 and Lundberg and Moore, 1986).

4. Web structures are composed of thin anastomosing and crosscutting cataclastic shear zones (a few $\mathrm{mm}$ in width) that affect disrupted sandstones (Cowan, 1982a; Byrne, 1984). 


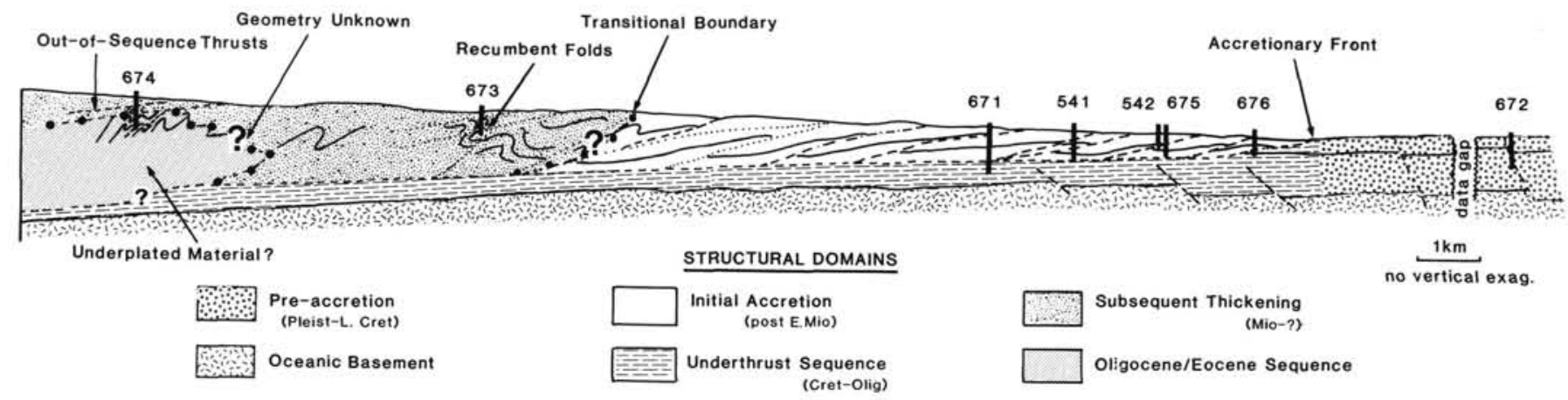

Figure 1. Schematic cross-section of the toe of Barbados Ridge accretionary complex illustrating the envisaged form of the structural domains in the region of ODP Leg 110. Age of sediments in each domain shown in brackets.

\section{PRE-ACCRETION STRUCTURES (SITE 672)}

Prior to accretion at the outer deformation front the abyssal plain section at the reference Site 672 was already affected by high-angle normal faults and an apparent zone of sub-horizontal shearing. This shear zone is located in the stratigraphic horizon that forms the basal décollement zone of the wedge to the west (Fig. 2). Small-scale features described in Mascle, Moore, et al. (1988) as mud-filled vein structures are associated with both the high-angle normal fault and low-angle shear zones. The vein structures, however, differ substantially in their morphologies between the two zones and probably have different origins.

\section{Small-Scale Structures}

Seismic reflection evidence and bore-hole control from DSDP Leg 78A and ODP Leg 110 indicate that the normal faults were predominantly active during the early depositional history of the sediments, prior to early to middle Eocene times (Mascle et al., 1986). However, there has been some recent rejuvenation (Brown et al., this volume). The normal faults have a lateral spacing of approximately $1 \mathrm{~km}$, dip at between $40^{\circ}-60^{\circ}$, and most have a down-throw to the east in this region.

There are mud-filled vein structures associated with a small normal fault zone at 110 mbsf (see Site 672, Fig. 2). Locally, the fault and veins affect upper Miocene to lower Pliocene sediments and are, therefore, most likely to be associated with the recent rejuvenation of the normal fault structures rather than earlier pre-middle Eocene phase. The veins are steep anastomosing curvilinear structures that are commonly continuous for 20 $50 \mathrm{~cm}$ down the core (Fig. 3A). They are concentrated in the muds of an interbedded sequence of muds, calcareous mud and marls, with their dip decreasing slightly in the mud layers (Fig. 3B). The veins are closely associated with more obvious throughgoing (i.e., completely core transecting) normal faults that displace bedding. Occasionally, local normal displacements occur across parts of the veins (Fig 3A). The displacement across individual veins commonly dies out toward their ends. The vein walls in the portions where displacements have occurred are generally polished and striated (down-dip motion indicated).

The vein structures developed in the deeper early Miocene section (170-190 mbsf, Site 672, Fig. 2) have more variable morphologies than those higher in the sequence and appear to have formed in response to a more complex strain history. Bedding dips in this early Miocene horizon are also disturbed over a 20 $\mathrm{m}$ thickness, with maximum dips of approximately $70^{\circ}$ being recorded (see bedding dip logs at Site 672, Fig 2). Sigmoidal vein arrays are common (Plates 1.3 and 1.4, Figs. 3A, 3D, and $3 \mathrm{E}$ ). Although it is not possible to orient the core, the bulk of the bounding surfaces of the sigmoidal vein arrays have sheet dips that are under $10^{\circ}$ and, therefore, appear to be associated with some sort of sub-horizontal shear couple. A smaller number also have slightly higher angle sheet dips $\left(10^{\circ}-30^{\circ}\right)$ and indicate displacements of a reverse or normal nature. A good example of a dilational normal fault (or extensional shear) occurs at this level (Plate 1.5). In the example shown in Plate 1.5, the fracture must have been an open void to account for down-filling of the fracture from the dark burrow in-filling. Plate 1.4 illustrates a common vein morphology, with sigmoidal veins tapping into a complex anastomosing network of veins developed along the borders of the shear zone (see also Fig. 3E). Shear across the central portions of the sigmoidal vein structures has foliated portions of the vein in-filling (Figs. 3C, 3E). Where second and third generations of mud-filled veins are developed, the intravein shearing is best developed in the early and most sigmoidal veins (Figs. 3C, 3E, and Plate 1.3). Occasionally, a later set of discrete shear planes developed subparallel to the sheet dip of the vein array. These shears cross-cut and displace the vein structures in some cases beyond the boundaries of the core so that displacements must exceed 6-10 cm (Plate 1.6 and Fig. 3D).

\section{Significance of Structures}

At Site 672 both groups of mud-filled vein structures (at 110 mbsf and 170-190 mbsf) appear to be related to shearing within the partly consolidated sediments. Differences in vein character between the two groups appear to depend in part on the orientation of the plane of shear with respect to bedding, the principal material anisotropy in the sediments. However, a relatively small but important component of layer-parallel slip also appears to be significant in both groups' development.

The recent reactivation of the normal faults is likely to be a response to flexural bending of the down-going plate as it is thrust beneath the wedge. In the case of the veins associated with the normal fault at Site 672, a shear couple at high angles to bedding appears to have been imposed. It seems likely that the veins developed as (minor) distributed shear surfaces around the larger normal faults. Indeed, the fracture geometries are similar to shear-band geometries generated in experimental studies (see Harris and Cobbold, 1984), where a simple shear couple is imposed obliquely across an anisotropic medium (Fig. 4). A certain amount of layer-parallel slip results in the generation of a complex set of shears with a variety of orientations (see Fig. 4). The development of such shears would probably involve volume collapse in the matrix during displacement (model B in Fig. 5) as described by Knipe (1986).

The generally low-angle sheet dip of the sigmoidal vein arrays at 170-190 mbsf (Fig. 2) suggest that sub-horizontal layer parallel slip is important in their development. Initially, in the presence of high pore-fluid pressures such sigmoidal veins may form as dilational features oriented perpendicular to the first in- 


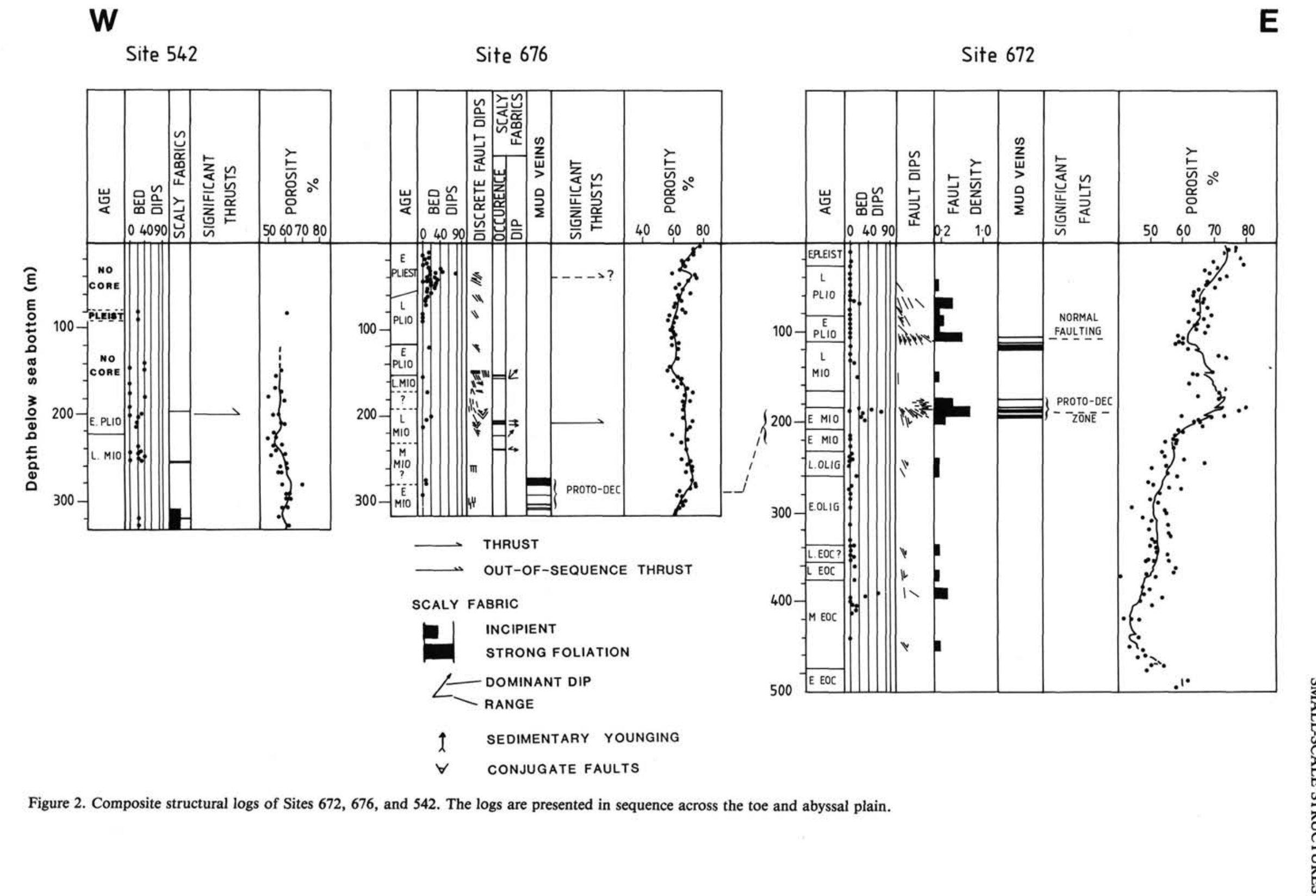

E 


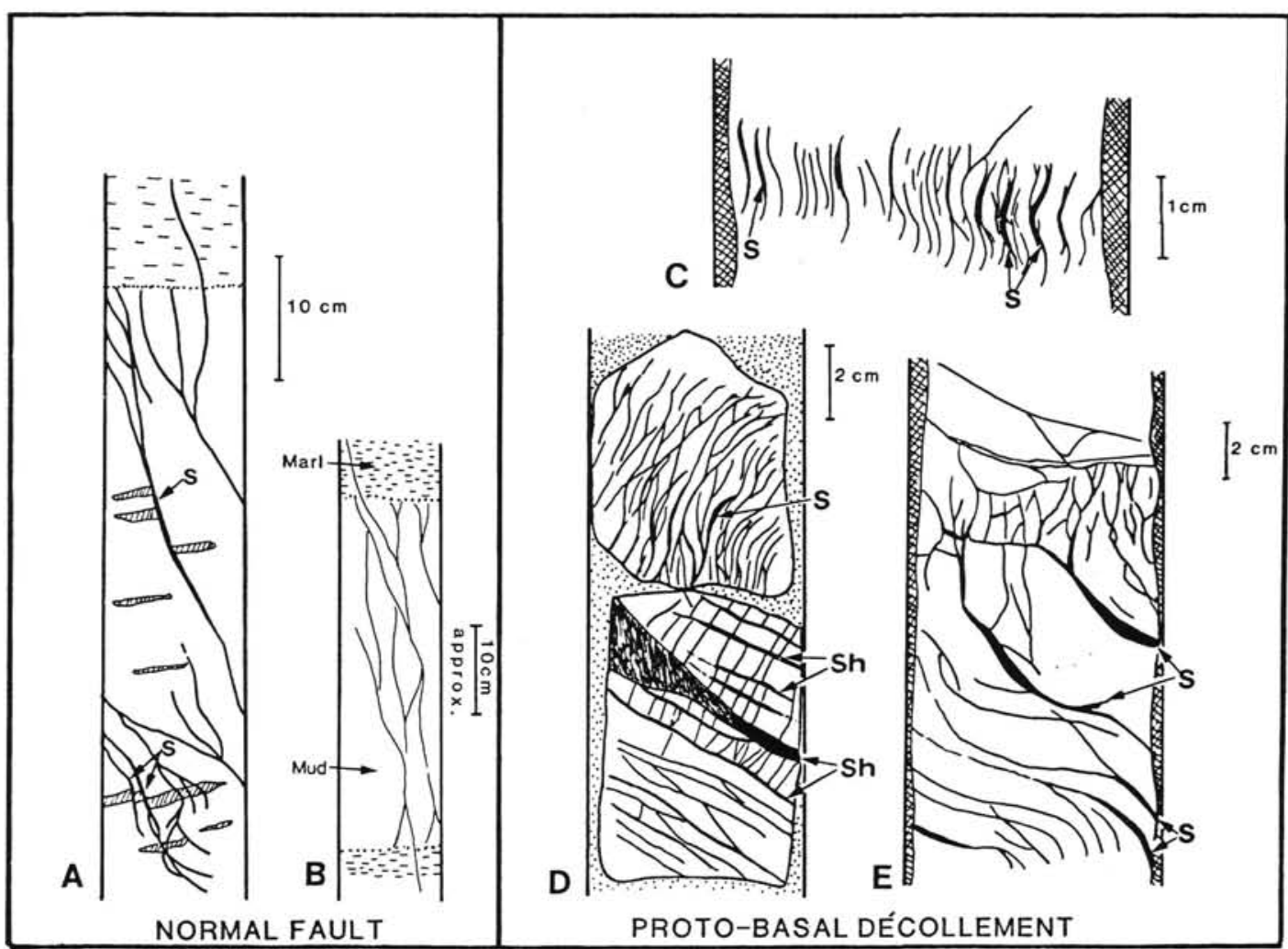

Figure 3. Mud-filled vein structures observed at Site 672. (A) Sketch of curvilinear vein structures in Core 110-672A$12 \mathrm{H}$ associated with normal fault zone at approximately $110 \mathrm{mbsf}$. Sheared portions of the veins are marked (S). (B) Interpretative sketch of overall geometry of curvilinear vein structures. (C) Line drawing of sigmoidal vein structures associated with proto-décollement horizon (Core 110-672A-20X, 190-200 mbsf). Note increased shearing toward central portions of vein. (D) Line drawing of anastomosing vein structures (Core 110-672A-21X, 190-200 mbsf) that form a complex sigmoidal vein set. These are cross-cut by lower angle shears (Sh). (E) Line drawing of well-developed sigmoidal vein set which taps into a marginal network of anastomosing veins. Central portions of veins are sheared (190$200 \mathrm{mbsf}$ ).

cremental extension (see Ramsay and Huber, 1987) in an individual minor shear zone (Fig. 6A). Progressive shear rotated their central portions toward the perpendicular to the direction of incremental compression, initiating the collapse of the vein. Subsequent deformation partitioning in the shear zone could then have imposed shear strains across the vein structure, resulting in the eventual foliation of the vein in-filling (Figs. 6B, 6C). It is also possible that fluids expelled during the closure of older rotated veins sets may have helped initiate later generations of dilational veins in the shear zone (Fig. 6D). Such an evolutionary path would correspond to model $\mathrm{A}$ in Figure 5.

The overall pattern of reverse and extensional shears in the lower Miocene horizon could be the products of two unrelated events of extension and compression. However, it is thought more likely that they are generated synchronously as Riedel, thrust, and principal (shear zone parallel) shears within a $20-\mathrm{m}$ thick, sub-horizontal shear zone (Fig. 7). The disturbed bedding (see bedding dip logs, Site 672, Fig. 2) is further independent evidence that strains have been taken up along this horizon. Alternatively, it is also distinctly possible that these minor folds may have rotated vein arrays with original sub-horizontal sheet dips, causing the variations described above. Indeed, the zone of disturbance does broadly correspond to that of the dipping arrays.

Two factors suggest that the proposed sub-horizontal shear zone at 170-190 mbsf (Fig. 2), may be associated with thrust tip propagation relating to the development of a proto-décollement zone. First, the proposed sub- horizontal shear zone is associated with the same lower Miocene horizon that forms the basal décollement of the accretionary wedge $5 \mathrm{~km}$ to the west. Second, geochemically distinguishable fluids appear to be migrating out of the accretionary wedge along this proto-décollement horizon to Site 672 and beyond at rates fast enough to suggest it is the site of interconnected fracture permeability (Wuthrich et al., this volume; Gieskes et al., this volume). If this shear zone is a proto-décollement zone, compressional stresses, and minor strains have been transmitted through the upper parts of the incoming section for at least $5 \mathrm{~km}$ in advance of the frontal thrust or macroscopic deformation front.

\section{INITIAL OFF-SCRAPING AND THICKENING-(SITES 676, 541, 675, 542, and 671)}

\section{Small-Scale Structures}

The basal décollement zone of the imbricate thrust system in the frontal region of the wedge is associated with a lower Miocene unit. A typical sequence of fabrics in the hanging wall sequence (Fig. 8) can be derived for an imbricate thrust packet at the toe of the Barbados Ridge complex (based on the general distribution of fabrics on the structural logs in Figs. 2 and 9). This vertical distribution of fabrics is proposed to relate to the strain history and deformation mechanisms operating during thrust-tip propagation and the initial period of thrust movement.

At the base of the thrust packet (Fig. 8) is a basal zone of intense scaly fabric forming a well-developed foliation. In the frontal regions of the wedge, scaly fabrics are restricted to shear 


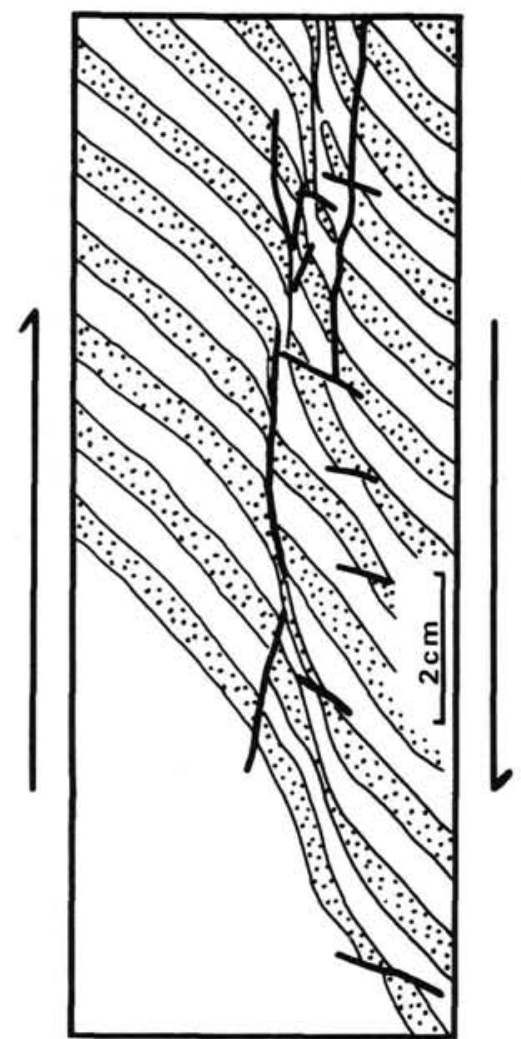

Figure 4. Possible analog for the development of mud-filled vein structures associated with the normal fault zone. Taken from a simple shear experiment using plasticine with an obliquely oriented anisotropy (Harris and Cobbold, 1984).



MODEL A

MODEL B

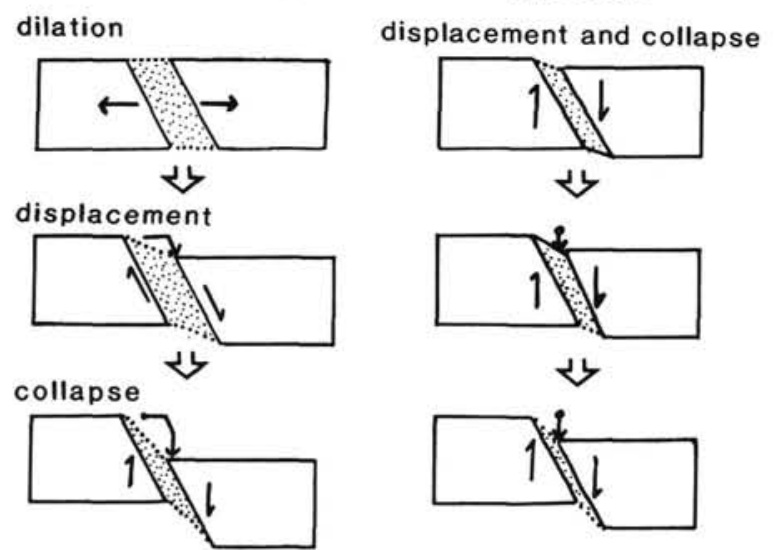

Figure 5. Two end-member models of mud-filled vein development taken from Knipe (1986). Model A involves a dilation-displacement-collapse history while Model B involves synchronous displacement and collapse.

zones involving sediments with porosities under $60 \%$, generally at burial depths of over 100-150 mbsf. At Site 671 (Fig. 9), for example, the upper thrust at 125 mbsf emplaces upper Miocene (approximately $60 \%$ porosity) over lower Pleistocene material (approximately $65 \%$ porosity). It has a large vertical throw, but
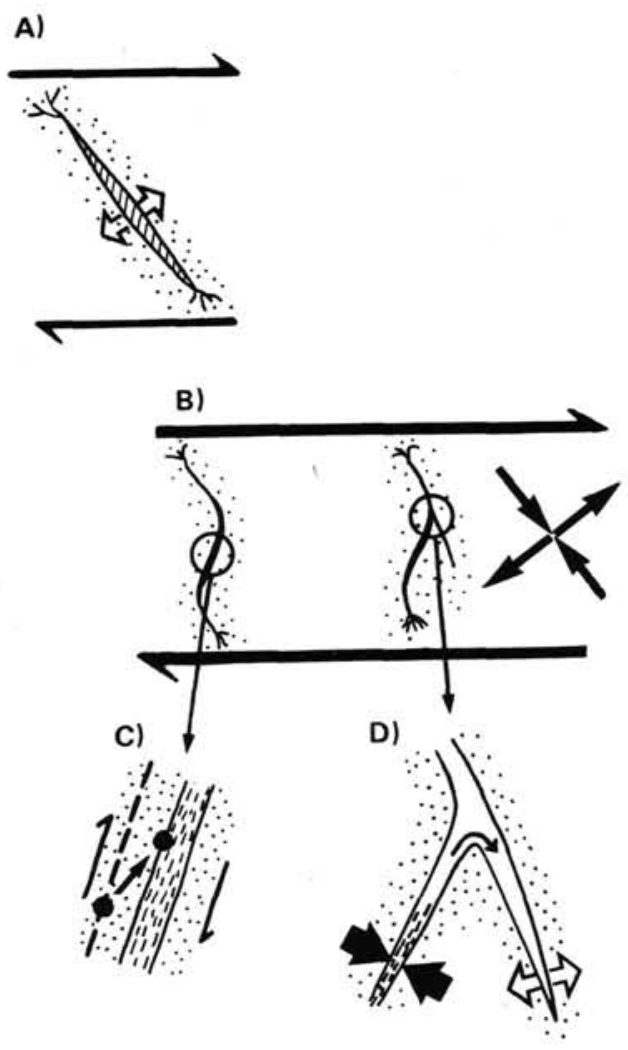

Figure 6. Sigmoidal vein development: (A) Initiation of dilational fracture perpendicular to the incremental direction of extension in a simple shear zone, (B) Continued simple shear rotates early formed fracture, (C) Rotation of fracture out of plane of incremental extension initiates collapse, and any strain partitioning along vein surface will shear the vein material, (D) Fluids expelled from collapsing vein may migrate into new dilational fractures opening perpendicular to incremental extension.



A)

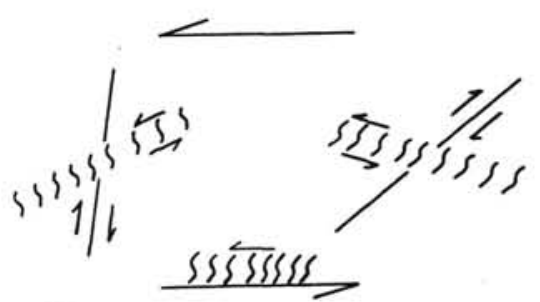

B)
Figure 7. A conjugate fault geometry (A) does not match the observed normal and reverse shear senses recorded on sigmoidal vein sets and individual faults. (B) The vein arrays may have developed in minor Reidel, thrust and shear zone parallel shears in a broad zone of simple shearing along the proto-décollement horizon.

at the point intersected by Hole 671 it is only associated with a 5 -mm shear zone of slightly darker material that does not exhibit the typical mesoscopic anastomosing fracture network that is typical of the scaly fabrics at greater depth. In addition, scaly fabrics only tend to be developed within argillaceous units and do not occur in the parts of the stratigraphic column with high carbonate contents.

The scaly fabrics are intense near the basal décollement zone (Fig. 8) and are oriented to form a crude planar foliation (Plate 2.2). However, commonly the scaly fabrics have foliation dips 


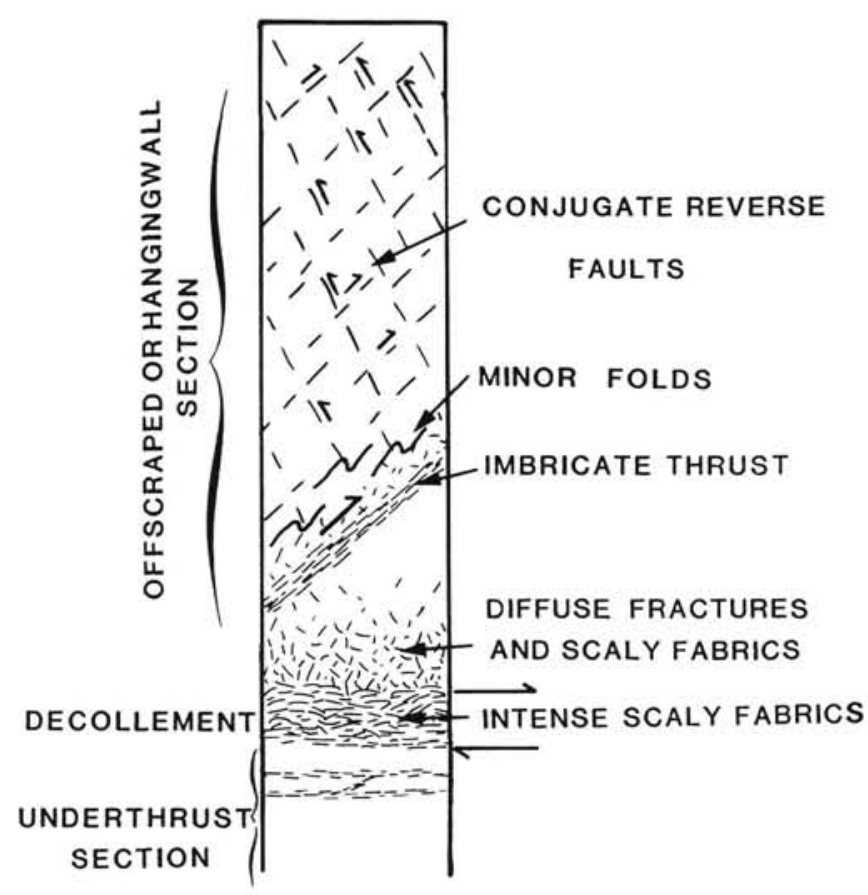

Figure 8. Schematic generalized cross-section of fabric disposition across the hanging wall and basal décollement near the toe of the Barbados Ridge.

that lie at $10^{\circ}-25^{\circ}$ to the general fault zone orientation. The observed scaly surfaces (including those oriented at relatively high angles to the shear zone boundaries) are polished and striated, indicating that they are slip surfaces. Microstructural studies of deformed muds exhibiting scaly type fabrics (Morgenstern and Tchalenko, 1967; Maltman, 1977; Carson and Berglund, 1986) indicate that, on a millimeter scale, strongly preferred orientations of phyllosilicate minerals occur within the fractures that define scaly fabrics. The orientations may be either parallel (Tchalenko, 1968), or at $25^{\circ}-30^{\circ}$ to the shear-zone boundaries (Carson and Berglund, 1986).

Immediately above the zone of the intense scaly fabrics associated with the basal detachment is a more diffuse zone of randomly oriented widely spaced fractures and additional minor low-angle thrust splays (Fig. 8). These define a diffuse irregular zone with no general planar foliation like that in the décollement zone. This diffuse zone dies out within a few tens of meters above the basal décollement zone. Variations in the bedding dip logs (see Figs. 2 and 9) indicate that minor folds are also developed in the lower regions of the thrust packets. Within the first $5 \mathrm{~km}$ of the accretionary front, bedding dips generally remain below $40^{\circ}-60^{\circ}$; however, there is evidence for a general increase in bed dips across the wedge (Fig. 10). Additionally, in the interior portions of the thrust packet, discrete faults are increasingly encountered (Fig. 8). These faults occur both as conjugate sets of reverse faults, which indicate a roughly horizontal compressive stress, and as individual reverse faults and occasional normal faults. All the reverse faults may be part of conjugate sets but we are limited to only a few observations of fault intersections in the core (these are marked on logs in Figs. 2 and 9). Sites 671 and 676 (Figs. 2 and 9) are the best illustrative examples of the form and distribution of these discrete structures. At Site 671 there is some indication that the discrete structures may be minor thrust splays as they shallow near the basal décollement zone.
Mud-filled vein structures also occur within the accretionary wedge. Locally, where the veins occur in close association with zones of shear and scaly fabric development, they appear to be disrupted. It may be that many are relict structures that were originally developed in the abyssal plain environment. As their overall relationship to structures in the wedge is not clear, we will not dwell on them in any more detail.

\section{Significance of Small-Scale Structures}

The intense scaly fabrics in the basal décollement zone and in the imbricate thrust zones appear to form in response to major displacements that may be on the order of tens to many hundreds of meters (see Brown et al., this volume), as will be discussed further in the next section. The diffuse zone of randomly oriented fractures that occur above the main detachment zone may be part of the process that results in fault zone thickening.

Minor folds and conjugate discrete fault sets in the hanging wall sequence (Fig. 8) appear to be initiated early in the sequence of off-scraping and thrusting. Large numbers of discrete reverse faults and conjugate sets are already present at Site 676 (see Fig. 2), which is within the first major anticlinal fold at the toe of the wedge. Such discrete, brittle structures may be attributed to compressive strains developed in the sequence above the basal décollement zone during the initial propagation of the thrust tip. Similarly, the minor folds at the base of the thrust packets are attributed to a "ductile bead" that may accompany the propagation of thrust tips (see for example, Williams and Chapman, 1983; Chapman and Williams, 1985).

\section{SUBSEQUENT THICKENING}

\section{Small-Scale Structures}

With subsequent deformation and thickening, a series of progressive changes occur in the structures developed in the frontal $18 \mathrm{~km}$ of the wedge: (a) The volume of the wedge affected by scaly fabrics and stratal disruption increases. (b) Bedding dips increase. (c) carbonate veining becomes abundant. (d) Folds become more numerous with the development of overturned sections. (e) Axial planar fabrics begin to develop, (f) possible "web structures" are developed.

One of the more obvious effects on structural style in response to continued accretion and thickening of the wedge is the increase in the volume of the wedge affected by scaly fabrics and stratally disrupted zones (see structural logs, Figs. 2, 9, and 11). Such disruption only affects relatively minor proportions of the wedge between Sites 676 and 671 within $5 \mathrm{~km}$ of the front. However, at Site 674 (18 km from the accretionary front) the major portion of the lower parts of the hole consist of scaly and stratally disrupted zones. At Site 674 , steep scaly foliation orientations are associated with thrusts (which emplace older over younger material, see Fig. 11). In addition, unusually intense horizontal scaly fabrics (Plate 2.2) are developed in narrow zones along out-of-sequence thrusts at 100 and 250 mbsf (Site 674, Fig. 2). These out-of-sequence thrusts cut out section and presumably transected an already structurally complex sequence (see Brown et al., this volume).

Carbonate veins are almost completely absent within $5 \mathrm{~km}$ of the accretionary front. The first main occurrences of carbonate veins are at Site 673, becoming abundant at Site 674. The calcite veins have a variety of morphologies and fabric associations. Internal vein morphologies range from fibrous to structureless. In places at Site 673, calcite veins occur as anastomosing networks that cross-cut otherwise relatively undeformed sediments. On the whole, veins are predominantly associated with zones of scaly clay development. Veins show syn-deformational relationships, both forming along scaly fabric fracture surfaces, being 
Site 671

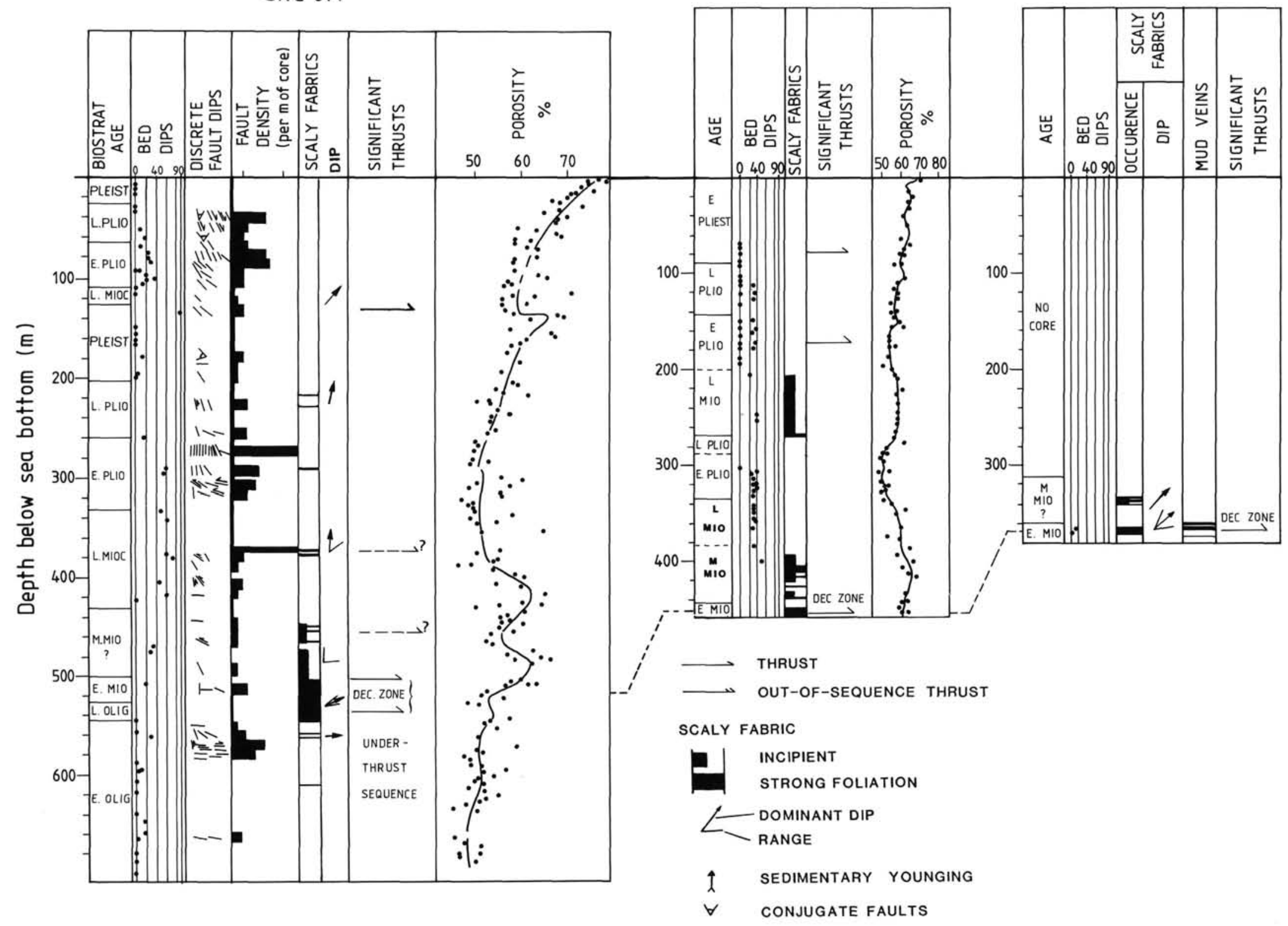



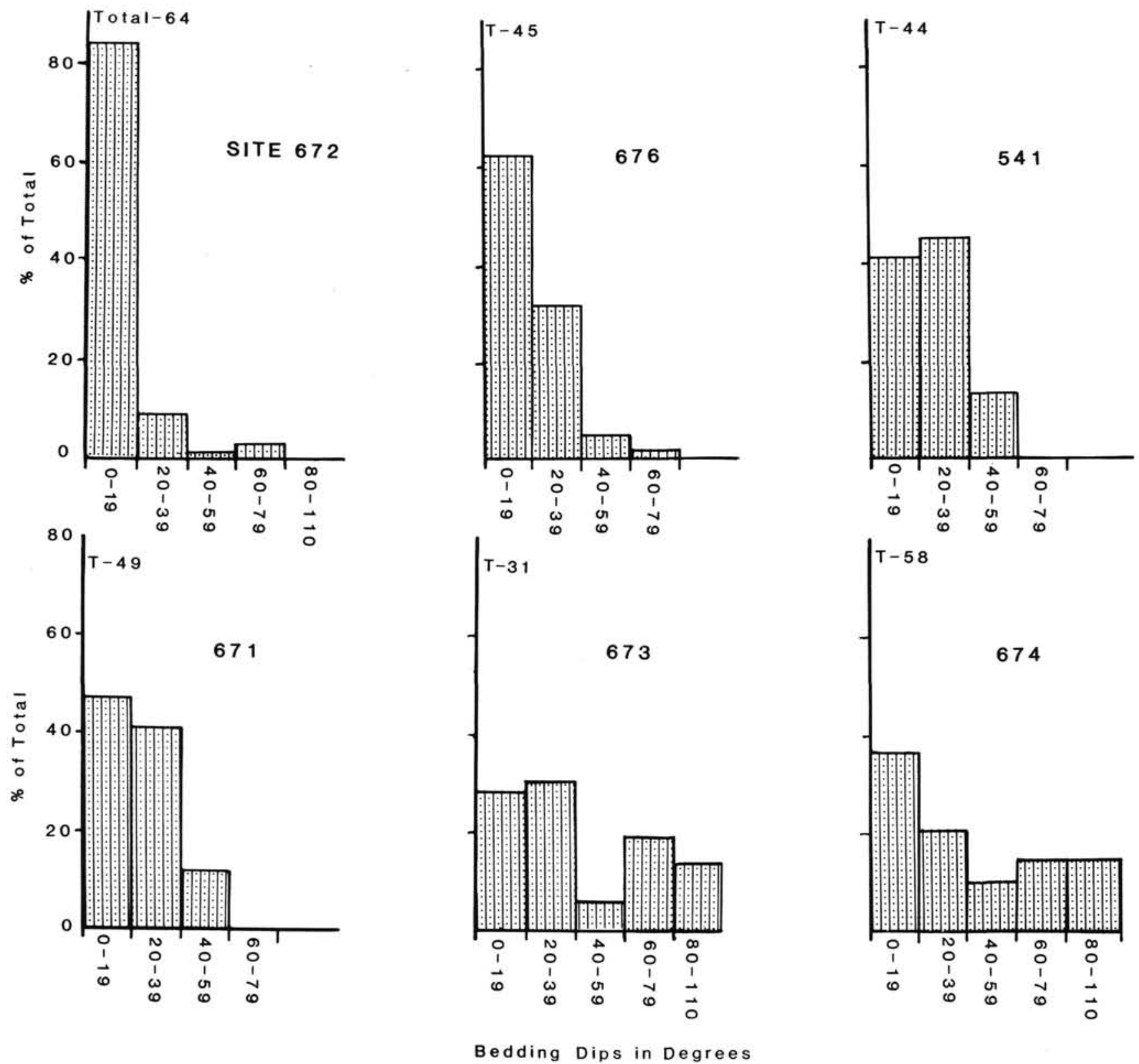

Figure 10. Bedding dip histograms illustrating the general increase in the recorded bed dips in cores from boreholes progressing westward across the accretionary complex (see Fig. 1 for relative position of holes). Note that overturned bedding at Sites 673 and 674 have been grouped into the $80^{\circ}-110^{\circ}$ field.

dismembered and folded in the scaly fabrics (Plate 2.3), and cross-cutting stratally disrupted material. At Site 674 , calcite veins first occur at depths of only $10 \mathrm{mbsf}$. They are, however, primarily concentrated in the Oligocene unit at the base of the hole below $300 \mathrm{mbsf}$. The calcite veins are usually associated with zones in which steep scaly fabrics occur. Surprisingly, they were not found in the low-angle zones of intense scaly fabric development associated with the more recent out-of-sequence thrusts (see Fig. 11).

The dip of bedding and scaly foliation within the wedge generally increases away from the accretionary front (Fig. 10 and Figs. 2, 9, and 11). In addition, folds and discrete faults in the more interior regions of the hanging wall sequence continue to develop in intensity and numbers during subsequent thrust displacement and thickening (e.g., compare logs for Site 676 and Site 671, Figs. 2 and 9). The tightness and asymmetry of folds increase arcward and this leads to the eventual development of overturned bedding at Sites 673 and 674 (see also Brown et al., this volume). At Site 674, a number of overturned to sub-recumbent folds with wavelengths that range between $1-2 \mathrm{~cm}$ and 10 $\mathrm{m}$ are observed in the cores in the Oligocene-Eocene section (below $250 \mathrm{mbsf}$ ). Abundant sedimentary structures made the identification of the larger folds (between 250 and $300 \mathrm{mbsf}$ ) relatively easy. These larger folds affect Eocene sandstones (beds $0.2-0.5 \mathrm{~m}$ in thickness) and have faulted hinges, indicating that these sandstones were at least partly lithified.

Although numerous folds were encountered in the Barbados Ridge, axial planar fabrics were only found in one example of a folded carbonate vein. This isoclinally folded vein occurs in a zone of intense scaly fabrics near the base of Site 674 (Plate 2.4). There has been a substantial amount of extension of the fold limbs in the plane of the vertical foliation. Extension was 
Site 674 (leg 110)

Site 673
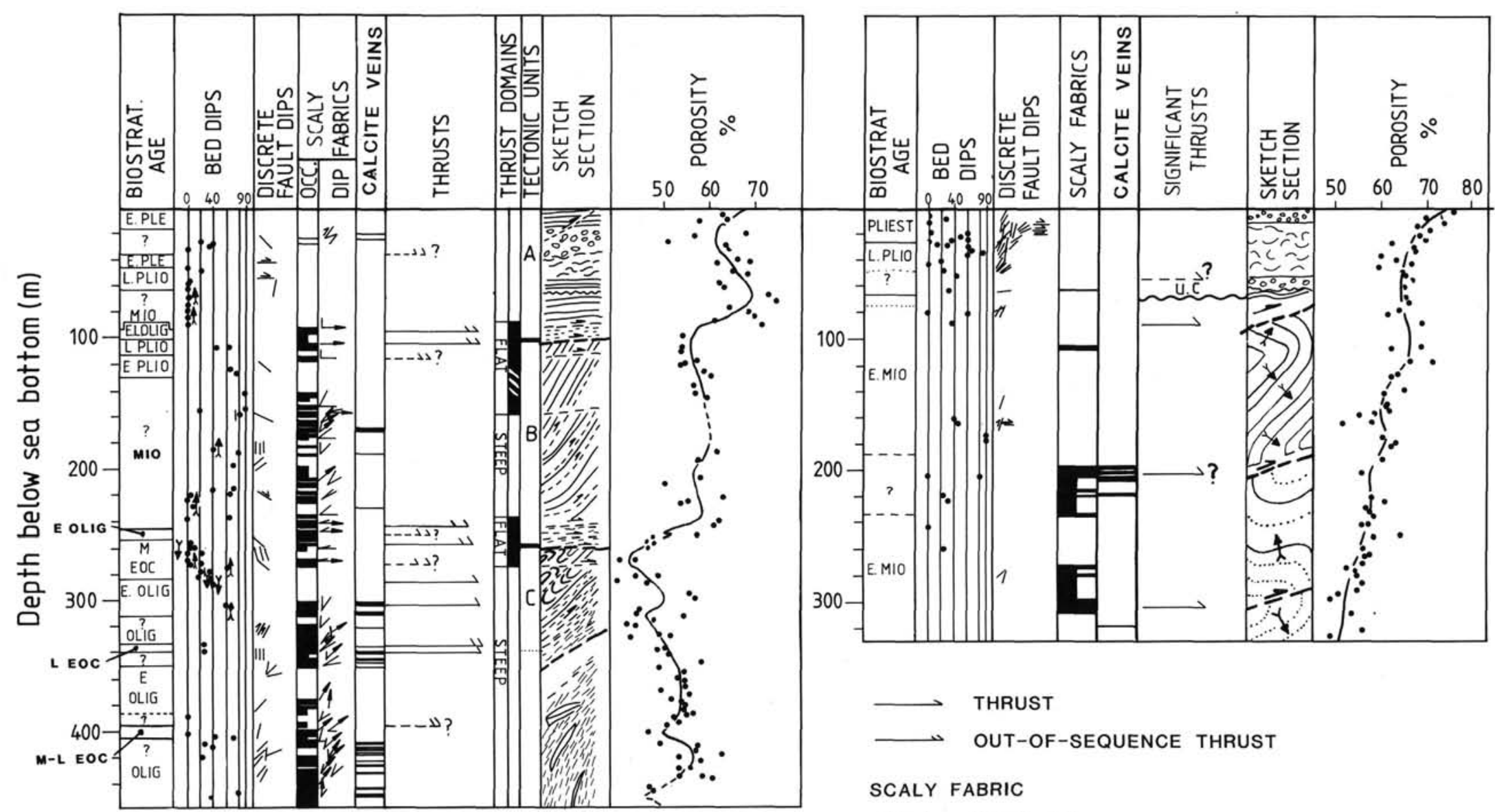

$\longrightarrow$ THRUST

$\longrightarrow$ OUT-OF-SEQUENCE THRUST

SCALY FABRIC

a INCIPIENT

STRONG FOLIATION

$\angle$ DOMINANT DIP

$\uparrow$ SEDIMENTARY YOUNGING

$\forall$ CONJUGATE FAULTS 
accommodated by slip on the scaly surfaces, which now define an "axial plane fabric" to the fold.

A number of sandstone beds in the middle and late Eocene units at Site 674 are affected by lattice works of dark gray anastomosing shear surfaces (Plate 2.5). Unfortunately, our samples collected on-board ship did not survive transport to the lab intact. However, the dismembered fragments broke along the fractures, revealing striated polished surfaces. They appear similar to the "web structures" described in dismembered sandstone units in ancient melanges in subaerially exposed accretionary complexes (See Cowan, 1982a; Byrne, 1984). In places a net layer-parallel extension can be demonstrated to be accommodated by similar looking shear zones (see Plate 3.3).

\section{Significance of Small-Scale Structures}

Two factors may account for the westward increase in the proportion of the accretionary wedge affected by scaly fabrics and stratal disruption. Most importantly, the density of thrusts and associated zones of scaly fabrics in the wedge increases during progressive accretion (e.g., compare structural logs of Sites 674 and 671). Secondly, there is an arcward thickening of the zones of scaly fabrics associated with the major thrusts. There appears to be a direct relationship between fault zone thickness and displacement along individual structures. Figure 12 is a plot of displacement vs. fault zone thickness along portions of the basal décollement zone and thrusts transected at Sites 676, 675, 541 , and 671 in the frontal $5 \mathrm{~km}$ of the wedge. Best estimates of

FAULT ZONE THICKNESS (meters)

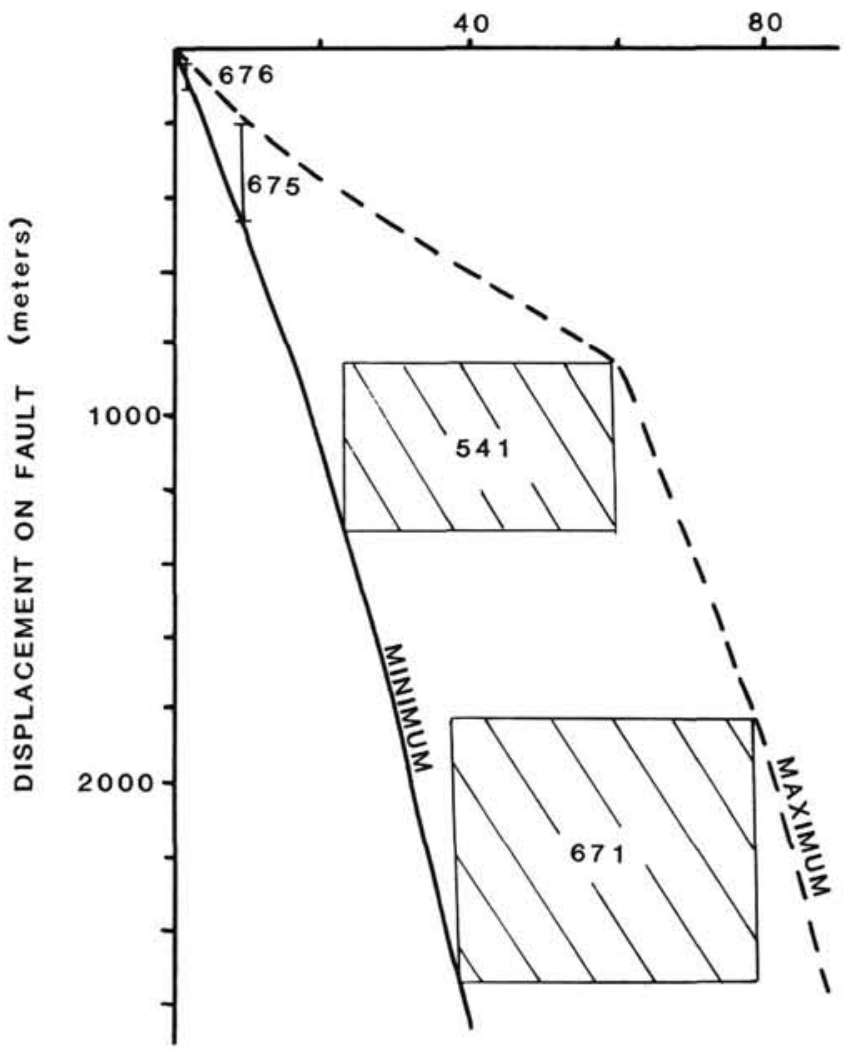

Figure 12. Correlation of fault-zone thickness against displacement. Displacement estimates for the sectors of the faults encountered in each borehole are taken from the line-balanced cross-section presented in Brown et al. (this volume). maximum and minimum fault displacement were derived from the two line-balanced cross-sections across the toe in Brown et al. (this volume). Fault-zone thickness came from measurements derived from cores recovered during DSDP Leg 78A and ODP Leg 110. Maximum and minimum fault zone thicknesses are indicated. These thicknesses are to some degree approximate as a result of the necessary subjectivity of the observations. Minimum values were taken as the thickness of the most intensely foliated region of the fault zone in which intense planar scaly fabric was developed. Maximum values are harder to define as they also include the more diffuse and irregular zone in which randomly oriented fractures and associated minor faults are developed.

Thickening of fault zones with increasing displacement suggests that they are loci of strain hardening as has been proposed by Moore et al. (1986). Moore and Byrne (1987) suggested that a combination of the following factors could lead to the abandonment of old fault surfaces in favor of new fractures in the surrounding previously unsheared regions: (a) Strengthening of fault zone material owing to porosity loss during shearing-related consolidation, (b) Localized drops in fluid pressure on fault surfaces, and (c) Reorientation of fault surfaces.

The majority of the scaly clay fabrics encountered during Leg 110 are proposed to have developed in response to simple shear associated with faulting (e.g., see foliation associated with the asymmetric folds in Plate 2.3). However, this may not be the case with regards to the scaly fabrics associated with the isoclinal fold (Plate 2.4) developed within the Oligocene section at the base of the Site 674. The current orientation of the structure suggests these scaly fabrics may have formed in response to, or at least accommodated, deformation associated with sub-horizontal flattening strains. This axial planar fabric could either be a modification of a pre-existing and subsequently rotated simple shear scaly fabric (Figs. 13A and 13B), or be the result of flattening strains only (Fig. 13C). The fabric itself is composed of polished striated fractures and, therefore, appears to have accommodated at least some slip (as the boudinaged fold limbs also demonstrate).

\section{UNDERTHRUSTED (AND “UNDERPLATED?”) SECTION}

\section{Small-Scale Structures in the Underthrust Section}

The penetration of the basal décollement zone of the wedge at Site 671 allowed the distribution of fabrics in the underthrust section to be documented for the first time in a modern accre-
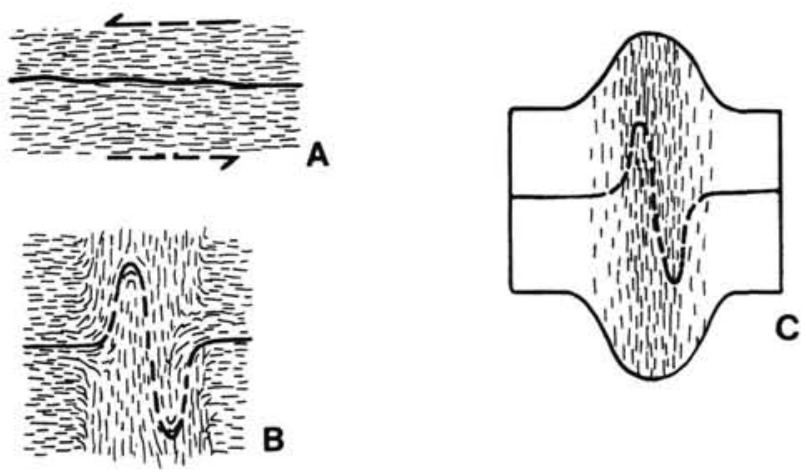

Figure 13. The scaly fabrics associated with the flattened isoclinally folded calcite vein (See Plate 2.4) may have developed from an original simple shear fabric (A) that has been modified by flattening (B). Alternatively, the scaly fabrics may have developed directly as a consequence of bulk shear during plane strain (C). 
tionary complex (See log of Site 671, Fig. 9). In general, very few faults were recorded in the underthrust Eocene-Oligocene section at distances greater than $40 \mathrm{~m}$ below the lower boundary of the zone of intense scaly fabrics (at $540 \mathrm{mbsf}$ ) associated with the basal déecollement. Dips of the few discrete faults encountered diminished away from the décollement zone and were dominantly sub-horizontal in most of the underthrust section. A possible incipient thrust, associated with disturbed bedding, may be propagating through the underthrust section at approximately $560-580$ mbsf. However, as a general rule this section is unaffected by reverse faults and the subhorizontal compressive stresses seen in the wedge above.

The hole at Site 671 was terminated in a middle Eocene sand body, when uncemented sands flowed into the hole and trapped the lower drill assembly. It is important to note the uncemented nature of these sands, especially in the light of the mesoscopically ductile fabrics that are a feature of the early deformational phase in parts of the Eocene section encountered in the wedge at Site 674 (see below).

\section{An Off-scraped or Underplated Section at Site 674?}

Oligocene and Eocene strata almost identical to the section now being underthrust beneath the basal décollement of the wedge were again encountered within the accretionary wedge in the lower regions of the hole at Site 674. Two possibilities exist that may account for their presence in the wedge. Either at some point in the past the basal décollement zone lay deeper in the incoming section and the Oligocene-Eocene unit was off-scraped at the front, or these units have been more recently underplated by duplex formation at a position further back from the accretionary front. An unambiguous determination between these two models is certainly not possible with the data derived from small-scale structures alone. However, it is argued from larger scale geometrical considerations in Brown et al., (this volume) that the underplating mechanism is probably the most likely explanation. Whatever model is taken, the early mesoscopic structures and fabrics developed in parts of the middle Eocene at Site 674 are different from those encountered in the off-scraped portions of the wedge nearer the toe (e.g., at Sites 671, 673, and 676), and it is interesting to speculate as to their origin.

\section{Small-Scale Structures in the Off-scraped or Underplated Section at Site $\mathbf{6 7 4}$}

The Eocene section at Site 674 contains interbedded sands, silts, and muds, interpreted to be turbidite deposits (Dolan et al., this volume). Early layer parallel extensional fabrics affect certain sands and silt horizons of the middle Eocene section. In Plates 3.2 and 3.3 the silt and sandstones have suffered layerparallel, mesoscopically "ductile" extension and boudinage. Irregular swirling interfingering of sand and unfoliated mud are also locally common (Plate 3.4). This early layer parallel "ductile" extension is accomplished by disaggregation and grain boundary sliding (unpublished data). Subsequent extension of the sandstone units occurred along discrete cross-cutting extensional shears (Plates 3.4 and 3.5). These discrete extensional shears are linked into well-developed scaly fabrics in the interbedded argillaceous units. It is possible that some of the web structures that exhibit layer parallel extension may have formed during this phase (e.g., Plate 3.1).

After the development of the early layer-parallel fabrics the Eocene section was then thrusted, folded, and veined by carbonate (see descriptions of structures at Site 674 in the Subsequent Thickening section above). The carbonate veins are associated with zones of scaly fabric and appear to have developed predominantly during the compressional phase. Early axial planar scaly fabrics in isoclinal folds also occurs locally in response to a principal subhorizontal axis of compression (see Plate 2.4).
Figure 14 summarizes the initial evolutionary sequence of fabrics proposed for the Eocene at Site 674.

\section{Significance of Early Small-Scale Structures}

Outside of the Eocene at Site 674, structures in the other portions of the off-scraped section of the Barbados accretionary wedge seem to have consistently formed in response to a subhorizontal (and approximately layer-parallel) axis of principal compression (see previous sections). In contrast, the Eocene strata at Site 674 have experienced early soft sediment layer-parallel extension, with structures that are more certainly associated with layer-parallel shortening only occurring late in the deformational sequence (Fig. 14). It is important to note at this point that the middle Eocene strata in which these fabrics occur are the oldest strata encountered so far in the wedge during both DSDP Leg 78A and ODP Leg 110. It is likely, therefore, that this stratigraphic unit was either at or very near a past basal décollement zone during the accretion of this portion of the wedge, and that this will have a bearing on their deformation history.

There may be a combination of reasons why these types of early layer-parallel extensional fabrics are confined to the Eocene section at Site 674: First, large competency variations in the bedded sands and muds of the Eocene section may have been important in enhancing the early layer parallel extension under simple shear stresses. Second, parts of the middle Eocene section may not have been well lithified or cemented during the early phases of their disruption (much like the Eocene sands encountered at the base of Site 671). Third, layer-parallel extension could have been enhanced by flattening as a result of the increasing vertical loads imposed by a wedge thickening above a basal décollement zone.

As a general note, the layer-parallel extensional features at Site 674 bear a marked resemblance to early deformational fabrics in some ancient accretionary complexes (see Cowan, 1982a;
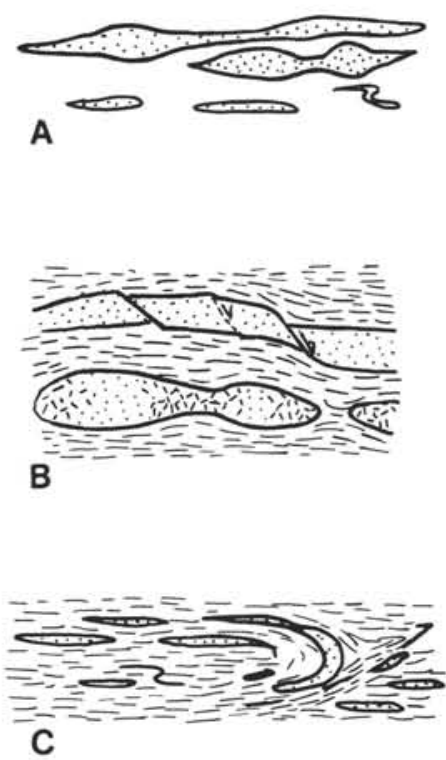

Figure 14. Proposed fabric evolution in Eocene section at Site 674. (A) Early mesoscopically ductile deformation in sandstones associated with layer- parallel extension. Scaly fabrics may or may not be developing in argillaceous matrix. (B) Layer-parallel extension of sandstones associated with discrete shear zones and web structures developing in more highly compacted units either later in the deformation sequence or in originally better-consolidated units. Scaly fabrics are well developed in the matrix. (C) Layer-parallel compression and associated folding and thrusting. 
Cowan, 1985; Byrne, 1984; Lash, 1985; Kemp, 1987; Fisher and Byrne, 1987). In particular, the sequence of fabrics in the Eocene at Site 674 is very similar to the fabric evolution that is described by Fisher and Byrne (1987) for the upper Cretaceous to lower Tertiary sediments of the Kodiak accretionary complex and by Lash (1985) for Paleozoic trench-fill deposits in the Appalachian orogen. In both of these ancient examples a vertical loading and flattening mechanism for sequences in and below basal décollements was proposed as an explanation for the origin of early ductile layer-parallel extensional fabrics. However, it must be said that the original geometries of these ancient systems are even less well constrained than our own observations in the modern Barbados wedge.

\section{SUMMARY}

Leg 110 documents a progressive change in small-scale structures from the abyssal plain and into the developing toe of the Barbados Ridge wedge (see Fig. 15). We have divided our descriptions into sections that deal with the pre-accretion, initial off-scraping, and subsequent thickening history of the wedge. We have also discussed the features of small-scale structures associated with underthrust (Site 671) and possible underplated material (at Site 674).

The abyssal plain section in advance of the accretionary front is affected by normal faults. Some normal faults have been recently reactivated, probably as a response to loading of the oceanic plate as it approaches the trench. Mud-filled vein structures that are similar to microshears are developed in response to this recent normal faulting phase. Leg 110 also provided evidence that a second mild deformational front or compressional "bowwave" may precede the macroscopic deformation front of the accretionary wedge (as typically identified on seismic reflection sections) by at least $5 \mathrm{~km}$. The bulk of the abyssal plain section appears not to have been greatly affected by these compressive stresses. However, we propose that the abundant sigmoidal mudfilled veins and minor folding in the early Miocene zone are associated with tip strains of the propagating décollement zone (Fig. 15B).

At the mesoscopic deformation front (Fig. 15A), compressional stresses become more obviously concentrated within the upper off-scraped parts of the section. Thrust-tip propagation is accompanied by minor folding and brittle faulting in the lower to mid parts of the hanging-wall sequences. Sporadic reverse faults indicating a subhorizontal axis of compression are concentrated within the interior regions of the hanging wall (Fig. 15A).

During subsequent thickening in the more internal regions of the wedge ( 12 to $18 \mathrm{~km}$ from the accretionary front at Sites 673 and 674), scaly fabrics become more pervasive as a result of larger numbers of thrust faults and additional fault-zone thickening in response to increasing thrust displacements (Fig. 15C). Increasing fault-zone thicknesses suggest that they are regions of strain hardening. Bedding and most fault zones progressively steepen arcward as a result of rotation during imbricate thrusting and folding. Asymmetric folds continue to develop until overturned bedding is eventually encountered at Sites 673 and 674. Additionally, carbonate veins become increasingly abundant arcward. The veins show syn-tectonic relationships with the development of scaly fabrics and are visible evidence of the role of scaly fabrics as pathways for the migration of fluids through the accretionary wedge. The carbonate veins are mostly associated with steeply oriented scaly fabrics. The absence of carbonate veins in the low-angle out-of-sequence thrust zones (at Site 674) may be due to there being insufficient time for the growth of veins systems in these potentially very recent features.
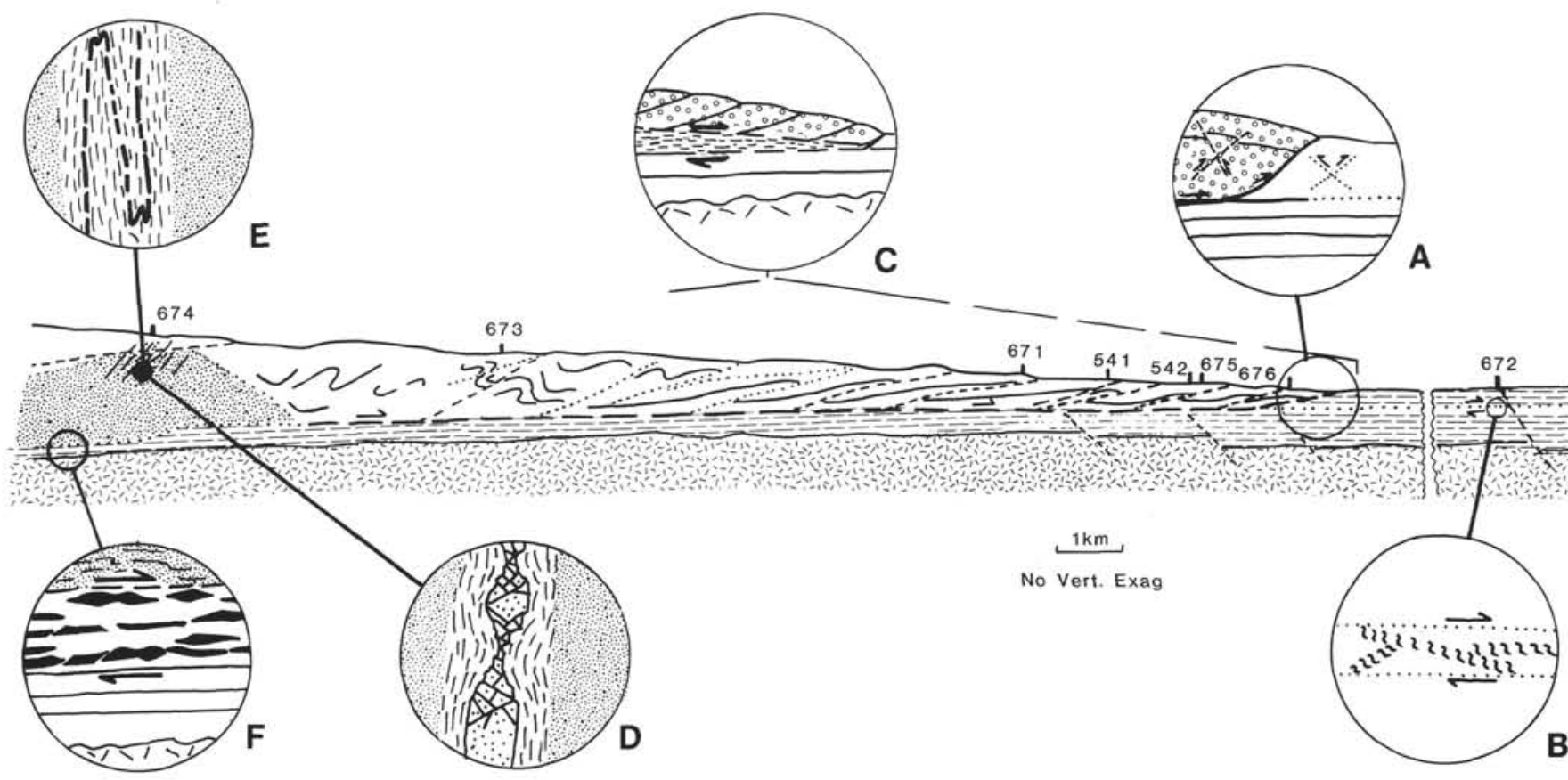

Figure 15. Schematic section depicting structural environments in the toe of the Barbados Ridge and some of the major associated small-scale structural elements that are proposed to have been observed during Leg 110. (A) Tectonic compressive stresses initiating conjugate reverse faults that are confined to the off-scraped section above the basal décollement. (B) Mud-filled veins associated with incipient shear and propagation of the basal décollement into the abyssal plain sequence. (C) Fault-zone thickening with increasing displacement leading to large volumes of scaly fabrics in the interior regions of the wedge. (D) Development of web structures in sandstones. (E) Flattening of folded carbonate veins in scaly fabrics in response to a sub-horizontal axis of compression. Vertical extension of limbs and early axial plane fabrics developed. (F) Early soft sediment layer-parallel extension in response to the combined effects of vertical loading and simple shear in a previous basal décollement zone along a middle Eocene horizon. 
With increasing depth at Site 674 , structures like web structures in sandstones (Fig. 15D) and flattened isoclinally folded carbonate veins with axial plane fabrics (Fig. 15E) were encountered. The intensity of these fabrics is perhaps surprising, particularly as the associated sediments still have porosities of 40 $60 \%$ and are at present structural depths of only 300 mbsf. These fabrics are similar to features encountered in ancient accretionary wedges. It is possible, therefore, that the ancient examples could have formed in the relatively early phases of accretion and deformation.

Oligocene and Eocene material were encountered within the wedge at Site 674. These stratigraphic units also form the present underthrust section beneath the basal décollement zone of the wedge to the east. Consequently, it appears they were either underplated or the basal décollement was situated at a much deeper level during initial frontal imbrication in the past. Within the oldest material (middle Eocene) in the wedge at Site 674 are a sequence of early soft sediment layer-parallel extensional fabrics. We suggest this section was subjected to simple shear and possible additional flattening strains in a previous basal detachment. Although we cannot definitely determine from small-scale structures alone whether the Oligocene-Eocene units at Site 674 are an underplated section or not, these early flattening fabrics are at least consistent with such an interpretation (Fig. 15F). If this sequence of events is correct, Leg 110 achieved the first penetration of underplated material in a modern accretionary wedge in both DSDP and ODP history.

\section{ACKNOWLEDGMENTS}

We thank Elliott Taylor, Casey Moore, Alain Mascle, Barrie Bernstein, and fellow shipboard scientific and ODP staff, without whom this work would not have been possible or as enjoyable.

\section{REFERENCES}

Byrne, T., 1984. Early deformation in melange terranes of the Ghost Rocks Formation, Kodiak Islands, Alaska. In Raymond, L. A. (Ed.), Melanges: Their Nature, Origin, and Significance: Geol. Soc. Am. Spec. Pap., 198:21-52.

Carson, B., and Berglund, P. L., 1986. Sediment deformation and dewatering under horizontal compression: experimental results. In Moore, J. C. (Ed.), Structural Fabrics Preserved in Deep Sea Drilling Project Cores From Forearcs: Geol. Soc. Am. Mem., 166:135150.

Chapman, T. J., and Williams, G. D., 1985. Strains developed in hanging walls of thrusts due to their slip/propagation rate: a dislocation model: reply. J. Struct. Geol. 7:762-762.

Cowan, D. S., 1974. Deformation and metamorphism of Franciscan subduction zones complex northwest of Pacheco Pass, California. Geol. Soc. Am. Bull., 85:1623-1634.

1982a. Deformation of partly dewatered and consolidated Franciscan sediments near Piedras Blancas Point, CA. In Leggett, J. (Ed.), Trench Forearc Sedimentation and Tectonics: St. Louis (Blackwell Scientific), 439-457. 1982b. Origin of "Vein Structure" in slope sediments on the inner slope of the Middle America Trench off Guatemala. In Aubouin, J., von Huene, R., et al., Init. Repts. DSDP, 67: Washington (U.S. Govt. Printing Office), 645-650.

1985. Structural styles in Mesozoic and Cenozoic melanges in the western Cordillera of North America. Geol.Soc. Am. Bull., 96:451-462.

Fisher, D., and Byrne, T., 1987. Structural evolution of underthrusted sediments, Kodiak Islands, Alaska. Tectonics, 6:775-794.

Harris, L. B., and R. Cobbold, 1984. Development of conjugate shear bands during bulk simple shearing. J. Struct. Geol., 7:37-44.

Kemp, A.E.S., 1987. Tectonic development of the southern belt of the Southern Uplands accretionary complex. J. Geol. Soc. London., 144:827-838

Knipe, R. J., 1986. Microstructural evolution of vein arrays preserved in Deep Sea Drilling Project cores from Japan Trench, Leg 57. In Moore, J. C. (Ed.), Structural Fabrics Preserved in Deep Sea Drilling Project Cores From Forearcs: Geol. Soc. Am. Mem., 166:75-88.

Lash, G. G., 1985. Accretion-related deformation of an ancient (early Paleozoic) trench-fill deposit, central Appalachian orogen. Geol. Soc. Am. Bull., 96:1167-1178.

Lundberg, N., and Moore, J. C., 1986. Macroscopic structural features in Deep Sea Drilling Project cores from forearc regions. In Moore, J. C. (Ed.), Structural Fabrics in Deep Sea Drilling Project Cores From Forearcs: Geol. Soc. Am. Mem., 166:13-44.

Maltman, A. J., 1977. Some microstructures of experimentally deformed argillaceous sediments. Tectonophysics, 39:417-436.

Mascle, A., Biju-Duval, B., de Clarens, P., and Munsch, H., 1986. Growth of accretionary prisms: tectonic processes from Caribbean examples. In Wezel, F.-C. (Ed.), The Origin of Arcs: Amsterdam (Elsevier), 375-400.

Mascle, A., Moore, J. C., et al., 1988. Proc. ODP, Sci. Results, 110: College Station, TX (Ocean Drilling Program).

Moore, J. C., Byrne, T., 1987. Thickening of fault zones: a mechanism of melange formation in accreating sediments. Geology, 15:10401043.

Moore, J. C., Roeske, S., Lundberg, N., Schoonmaker, J., Cowan, D., Gonzales, E., and Lucas, S., 1986. Scaly fabrics from Deep Sea Drilling Project cores from forearcs. In Moore, J. C. (Ed.), Structural Fabrics in Deep Sea Drilling Project Cores From Forearcs: Geol. Soc. Am. Mem. 166:55-73.

Morgenstern, N. R., and Tchalenko, J. S., 1967. Microscopic structures in Kaolin subjected to direct shear. Geotechnique, 17:309-328.

Ramsay, J. G., and Huber, M. I., 1987. The Techniques of Modern Structural Geology: New York (Academic Press).

Tchalenko, J. S., 1968. The evolution of kink-bands and the development of compression textures in sheared clays. Tectonophysics, 6: 159-174.

Williams, G., and Chapman, T., 1983. Strains developed in the hanging wall of thrusts due to their slip/propogation rate: a dislocation model. J. Struct. Geol., 5:563-571.

Date of initial receipt: 23 March 1988

Date of acceptance: 22 March 1989

Ms 110B-141 

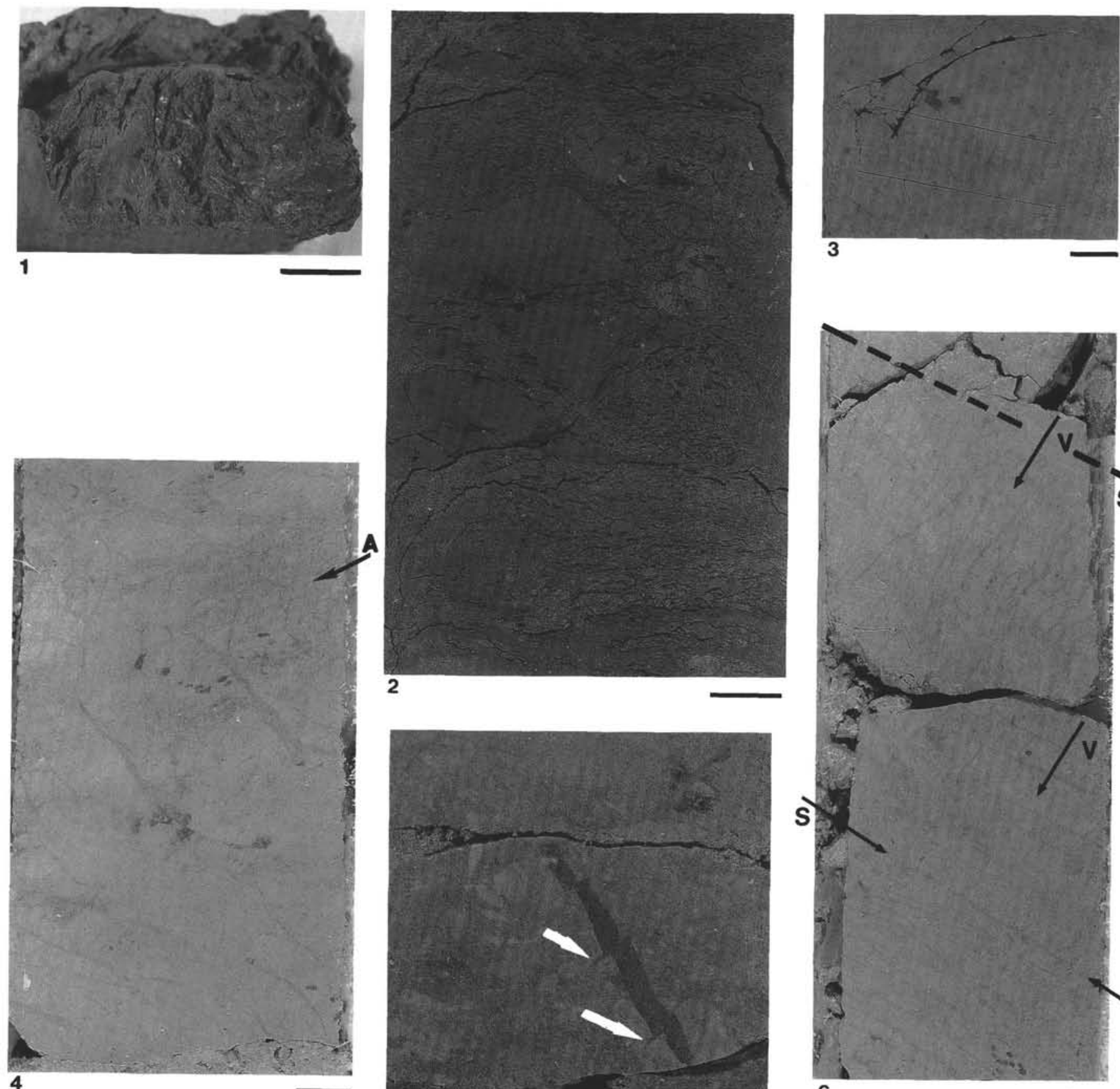

2
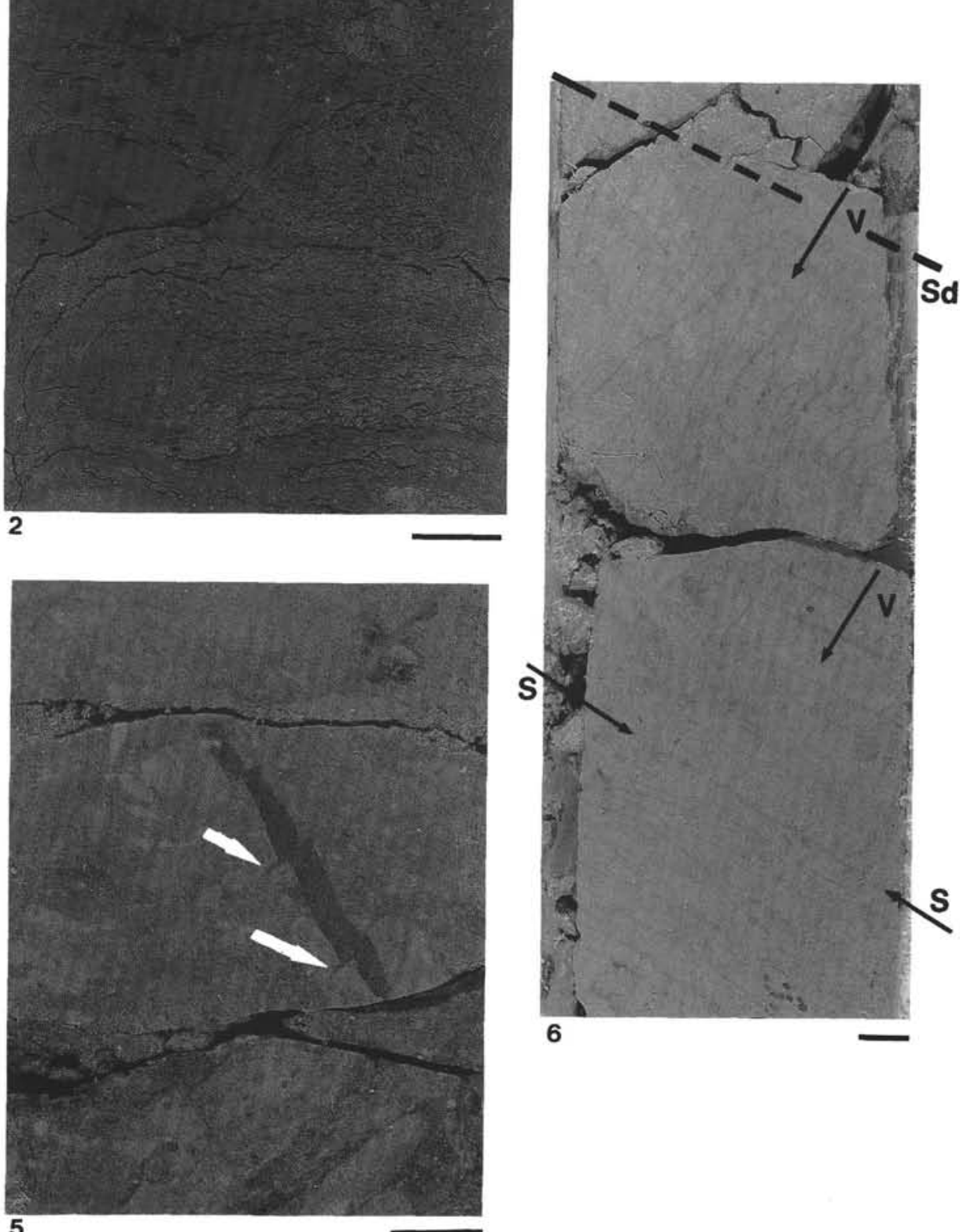

Plate 1. 1. Close-up of relatively intense scaly fabrics developed in a minor thrust zone in the Miocene section (Site 671,375 mbsf). 2. Stratal disruption affecting Miocene muds, with fragments of more competent units enclosed in scaly clays (Miocene, Site 674, 250 mbsf). 3. Sigmoidal mudfilled vein array developed in lower Miocene muds. Note low-angle sheet dip of the array denoted by black lines (Site 672, 180 mbsf. 4. Sigmoidal mud-filled vein structure in lower Miocene mud. Note complex chicken wire network of small veins (region of point A) developed along the array's margins (see also Fig. 3E, Site 672, $184 \mathrm{mbsf}$ ). 5. Dilational normal faults displacing a dark burrow in the lower Miocene mud. Note the dark burrow filling (arrows) along fault surface below burrow (Site 672, $182 \mathrm{mbsf}$ ). 6. Anastomosing mud-filled vein structures (V) in lower Miocene sediment, cross-cut by lower angle shears (S) oriented sub-parallel to the sheet dip (Sd) of the array (Site $672,185 \mathrm{mbsf}$ ). Scale bar is $1 \mathrm{~cm}$ long. 

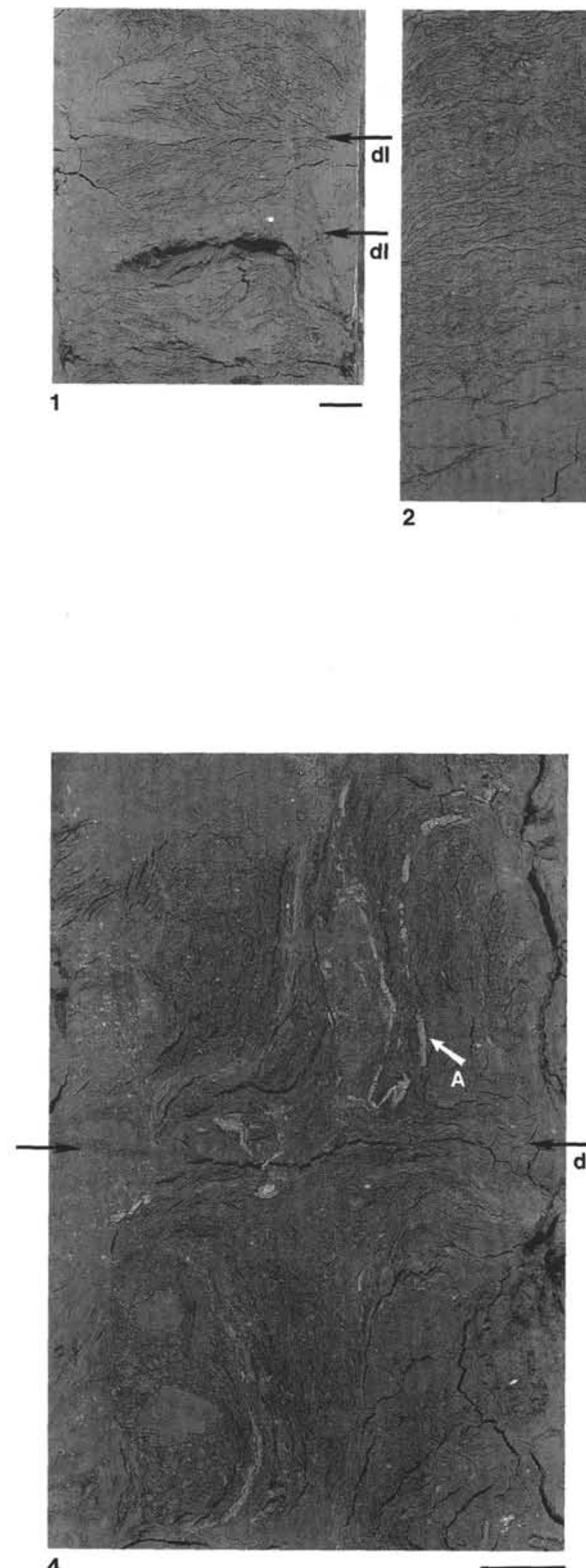

4

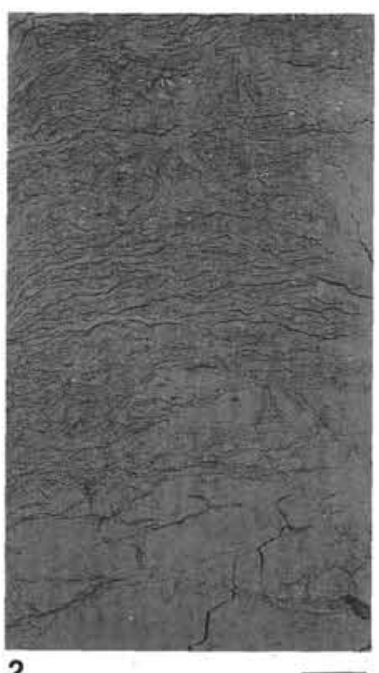

2
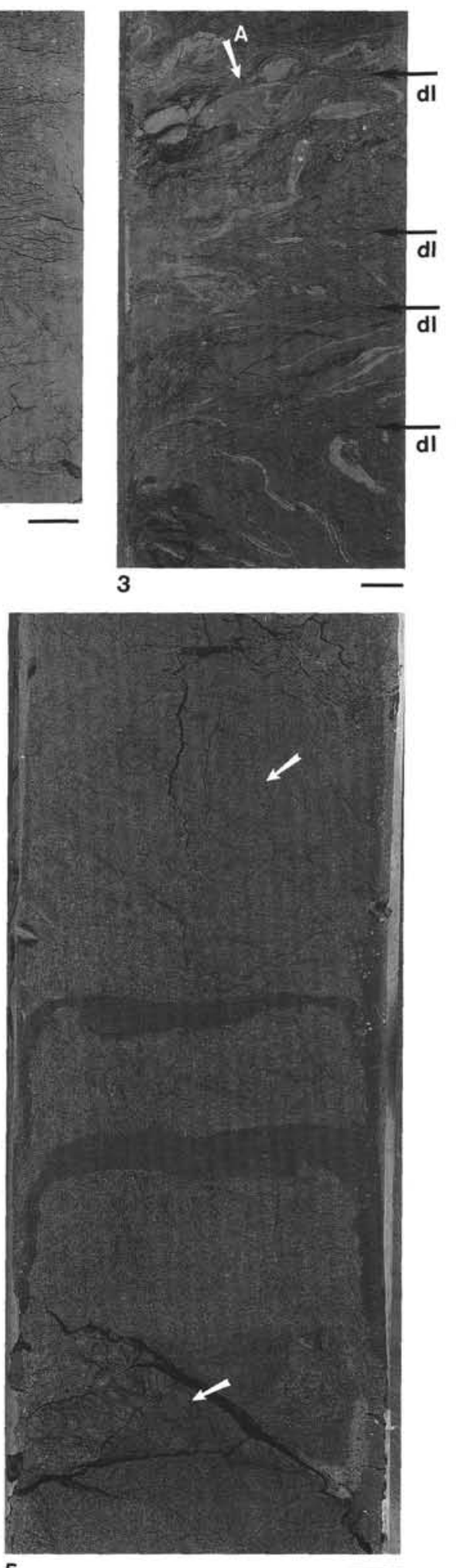

5

Plate 2. 1. Intense scaly fabrics in lower Miocene unit that is disrupted along basal décollement of the accretionary wedge. Note the moderate dip of the fabrics. 2. Intense sub-horizontal scaly fabrics developed along out-of-sequence thrust affecting Miocene muds (Site 674, 240 mbsf). 3. Folded and disrupted carbonate veins in Oligocene muds affected by scaly fabrics (Site 474,420 mbsf). Note the asymmetrically folded carbonate vein (Point A). 4. Isoclinally folded carbonate vein (A) in intense scaly fabrics which define an axial plane fabric. Note the extension and boudinage of the fold limbs (Site 674, $450 \mathrm{mbsf}$ ). 5. Dark seams (most intense in regions of arrows) are cross-cutting shear zones (web-like structures), developed in middle Eocene sandstones (Site 674, $260 \mathrm{mbsf}$ ). dl shows horizontal drilling disturbance along which core has rotated about vertical axis. Scale bar is $1 \mathrm{~cm}$ long. 

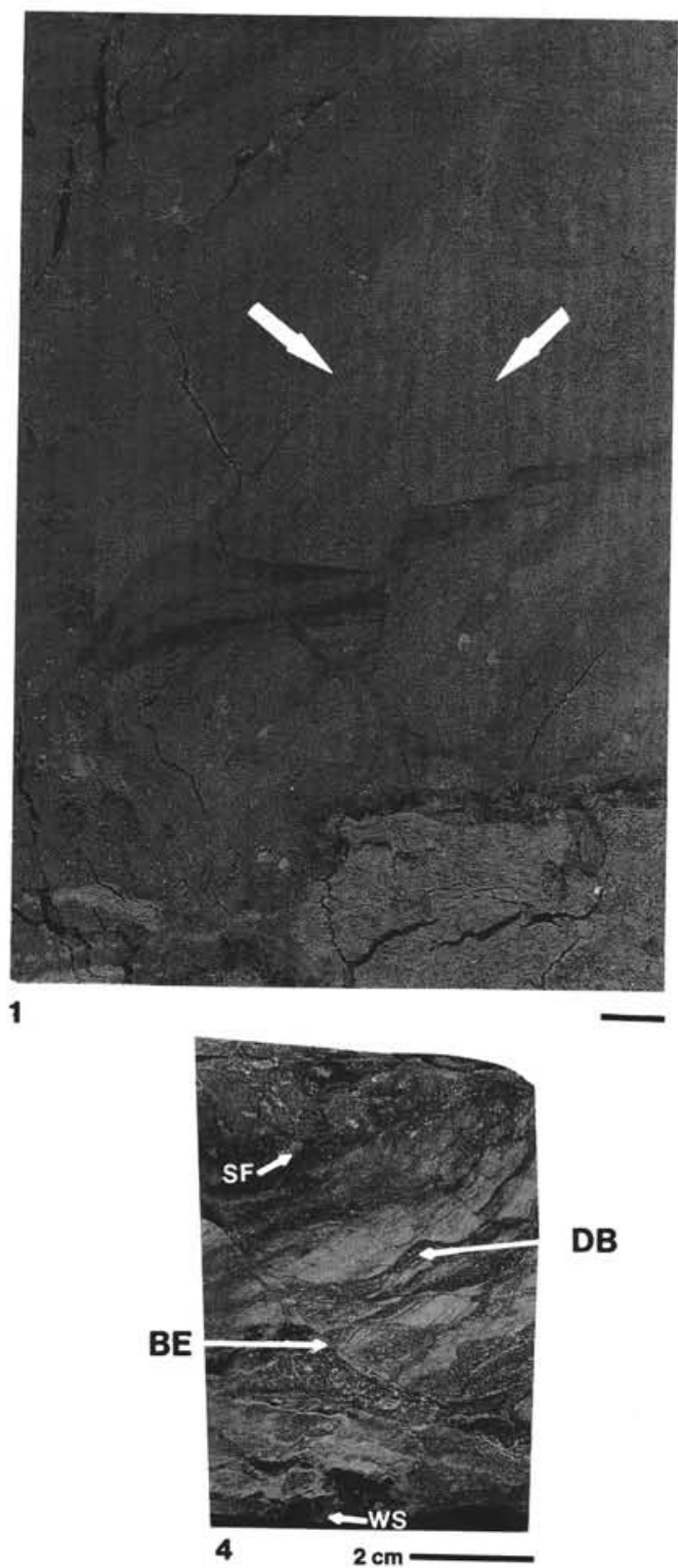
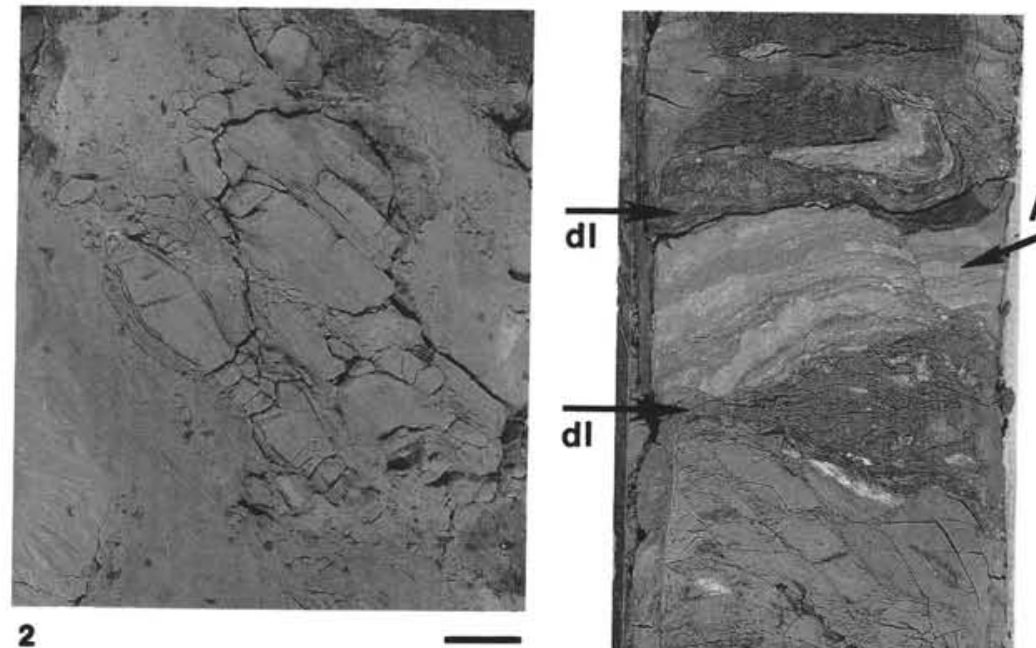

dl

2

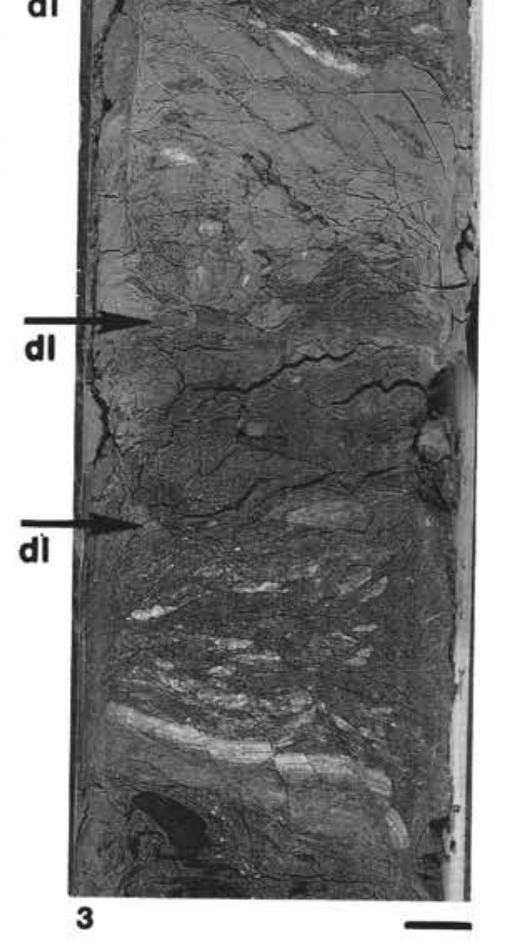

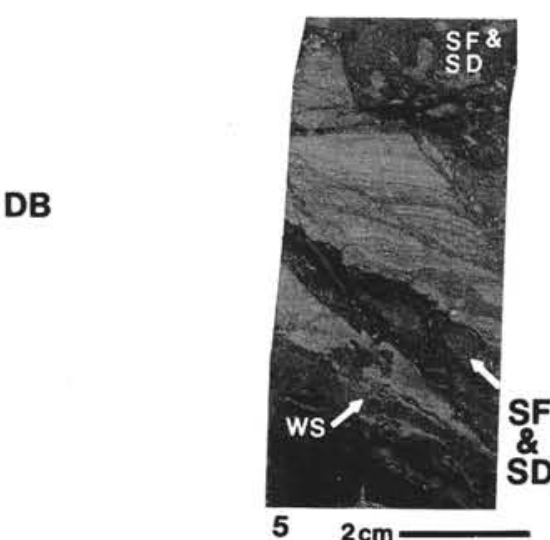

Plate 3. 1. Extensional shears (arrows) developed in late Eocene sandstones (Site 674, $355 \mathrm{mbsf}$ ). 2. Necking and layer-parallel boudinage in middle Eocene sand and siltstone units. There is some development of brittle extensional fractures in the most extended regions (Site 674,260 mbsf). 3. Section of core illustrating the range of fabrics formed in middle Eocene unit with varying competence (Site 674, 270 mbsf). Panels 4 and 5 are slabs cut from the siltstone unit that has experienced soft sediment layer-parallel boudinanage denoted by arrow (A). 4. Disrupted siltstone, note both early layer-parallel mesoscopically ductile extensional features (DB) and later oblique discrete extensional features (BE). Note irregular wispy sand lenticles (WS) that may have formed by particulate disaggregation in muds near base of photo. 5. Early layer-parallel ductile and later oblique discrete extensional structures affecting siltstones. SF, scaly fabrics. SD, stratal disruption. dl shows horizontal drilling disturbance along which core has rotated about vertical axis. Scale bar is $1 \mathrm{~cm}$ long except for 4 and 5 . 